\title{
sciendo
}

Research Article

(C) 2019 Savina et.al. This is an open access article licensed under the Creative Commons Attribution-NonCommercial-NoDerivs License (http://creativecommons.org/licenses/by-nc-nd/3.0/).

\section{Efficiency Improvement of Long-Term Care for Senior Citizens in the Russian Federation}

\author{
Galina I. Andryushchenko ${ }^{1}$ \\ Margarita V. Savina ${ }^{1}$ \\ Alexander A. Soldatov ${ }^{1}$ \\ Albina A. Bikbulatova ${ }^{1}$ \\ Ksenia A. Samofatova ${ }^{1}$ \\ ${ }^{1}$ Russian State Social University, \\ Moscow, Russia
}

Doi: 10.2478/ajis-2019-0017

\begin{abstract}
This paper examines organizational support to the long-term care system which consists of the regulatory, infrastructural, financial, staffing, methodological and information technology support. The authors have analyzed the data provided by the Federal State Statistics Service of the Russian Federation reflecting the count of pensioners receiving the old-age pensions and pension average size, as well as the current state of social service organizations in the Russian Federation. The analysis results were used to validate a necessity to introduce the system of long-term care for senior citizens and people with disabilities. It was determined that it is possible to create infrastructure and financial support to enable functioning of this system by implementing the public-private partnership projects. The authors proposed measures for efficient implementation and functioning of the long-term care system in the Russian Federation. The undertaken analysis brought us to the conclusion that in the Russian Federation there is a need to take certain measures aimed at: development of social infrastructure facilities for the disabled and senior citizens; construction of new modern infrastructure; active engagement of socially committed non-profit organizations for the provision of social and medical services included in the long-term care for senior citizens.
\end{abstract}

Keywords: long-term care system, social sphere, social services, senior citizens, geriatrics

\section{Introduction}

In 2018, the population of the Russian Federation was 146.9 million, of which $31.7 \%$ (46.5 million people) were the pensioners (Vlasova et al., 2018; Long-term Care System, 2019).

The average life expectancy is 72.5 years. The demographic ageing of the population, which rather soon will need long-term care, is an inevitable fact (Andryushchenko, 2011, p. 161). It should be emphasized that the annual increase in the number of elderly people makes it impossible for the social service organizations to fully cover the need in their services.

Among the hard-to-solve problems associated with meeting the needs of the elderly, the high cost of long-term care is the most pressing. Other issues listed here by degree of importance include development of services for the elderly and disabled (how will such services be developed 
and by who); payment mechanisms for long-term cart, and finally, selection and training of fit-forpurpose staff.

The long-term care implies a huge amount of the so-called low-tech assistance in basic everyday tasks of the elderly, helping them to minimize or partially compensate for the loss of their self-sufficiency.

The long-term care is intended to:

1. Create conditions for the timely and fullest satisfaction of the needs of senior citizens in social and medical services.

2. Improve a procedure for identifying the citizens in need of long-term care.

3. Organize cross-departmental interaction between social service organizations and medical organizations, including synchronization of information systems in certain aspects, like the amount of necessary information about a person's condition and means to pass it to his/her family.

4. Develop and support family care for the elderly.

\section{Literature Review}

The urgency of this topic is illustrated by the sharp rise in the number of publications by researchers and experts on the issues concerning the ways to organize and implement the long-term care system in the constituent entities of the Russian Federation.

The researchers analyze the features intrinsic to the long-term care and the ways to provide it, and distinguish pros and cons of implementation of the long-term care system for the senior citizens: Vlasova T., Scherbak N. and Bondarchuk A. (2018), Ponomareva T.A. (2018).

Bektleeva D.E., Pritvorova T.P. (2014), Shestakova E.E. $(2015,2017)$ in their works explore the best international practices in the management of the long-term care for the elderly, and also describe different long-term care organizational and funding models used in OECD countries. The authors describe in detail the long-term care funding options in OECD countries: through the use of tax revenues, insurance mechanism and co-payment system.

Joseph L. Matthews, Marquand B. et.al. (2016) support the idea that the long-term care should be covered by insurance. In their works they note that the insurance certificate for long-term care cover the medical expenses, if an elderly person has a chronic illness, disability or mental disorder, and such medical care should be given either in their own homes, or in a nursing home, or in a specialized residential complex. Most people purchase insurance certificate of this kind at the age from 50 to 60 years.

\section{Research Methodological Framework}

The research objective was to aggregate the opinions of the experts on the long-term care and, with reliance on the analysis results, develop measures for efficient implementation and functioning of this system in the Russian Federation.

Research tasks:

- analyze the data provided by the Federal State Statistics Service of the Russian Federation reflecting the current state of the social service institutions;

- validate a necessity to introduce the system of long-term care for the senior citizens;

- examine organizational support to the long-term care system;

- outline measures for efficient implementation and functioning of the long-term care system in the Russian Federation.

Such methods as comparative, systemic and structural analysis and statistical data processing methods constituted a methodological basis for this research.

Global practices of long-term care have proven tools, including methods that are used by the World Health Organization to assess the long-term care needs and requirements (Organization of Long-Term Care for the Elderly and Disabled in Moscow, 2019, p. 12), which were also used in the research process. 


\section{Results}

One of the main demographic trends of 2011-2018 in the Russian Federation is the aging of the nation, which is manifested in a steady growth of the population (Passport of the National Project "Demography", 2018; Passport of the Federal Project "Senior Generation", 2019; Retirement Insurance for Seniors, 2019; Russian Federation Government Decree from 15.04.2014 N 296, 2014; Social Services for Senior and Disabled Citizens, 2019) older than the employment age (Figure 1).

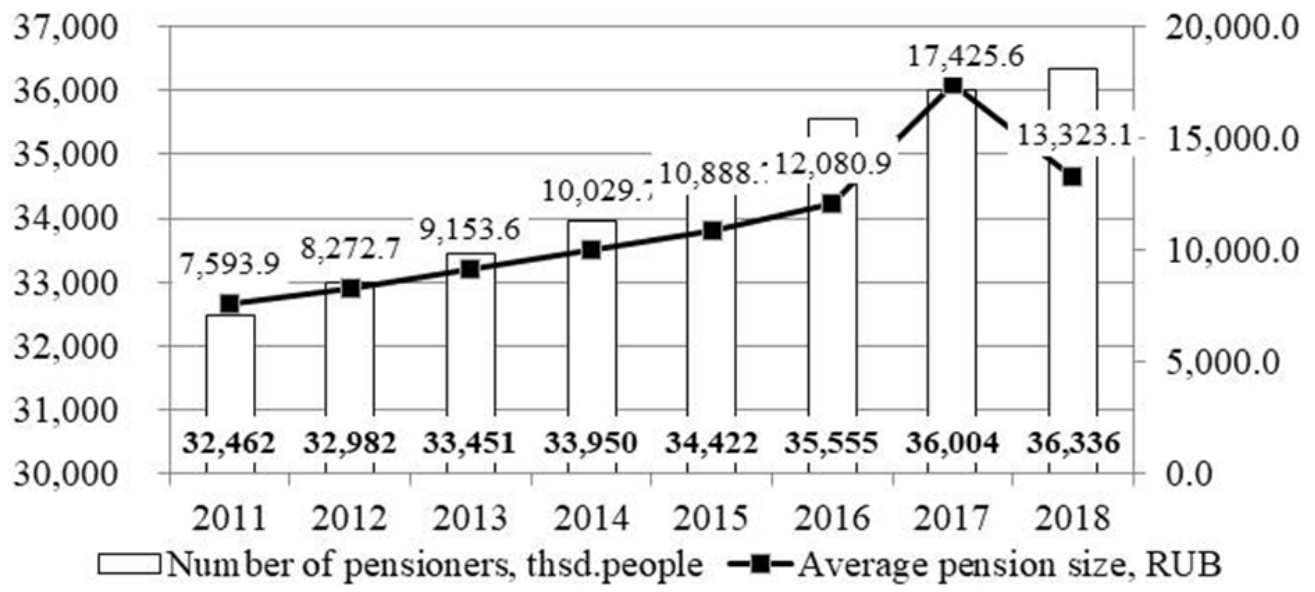

Figure 1: Count of pensioners in the Russian Federation receiving old-age pensions and pension average size

Source: Authors based on the sources (Passport of the National Project "Demography", 2018; Passport of the Federal Project "Senior Generation", 2019; Retirement Insurance for Seniors, 2019; Russian Federation Government Decree from 15.04.2014 N 296, 2014; Social Services for Senior and Disabled Citizens, 2019)

A significant role in social support for the elderly was played by the system of social services created in 2013, which provides social and domestic, socio-medical, socio-legal, sociopsychological services and socio-economic services (Babakaev et al., 2016, p. 13; Ulyanchenko, et al., 2016, p. 15; Federal Law of the Russian Federation from 28.12.2013 N 442-FZ, 2013).

The efficiency of this system depends directly on the accessibility of social service infrastructure to the senior citizens, including:

- urgent social services agencies (departments);

- in-home social services centers and departments;

- $\quad$ specialized departments for in-home social and medical services;

- residential social care facilities;

- social recreation centers;

- $\quad$ social rehabilitation units (Kornilova, 2017, p. 112; Pritvorova \& Bektleeva, 2014, p. 70).

Still one of the topical issues is the low accessibility of the infrastructure of urgent social services for the senior citizens (Figure 2). 


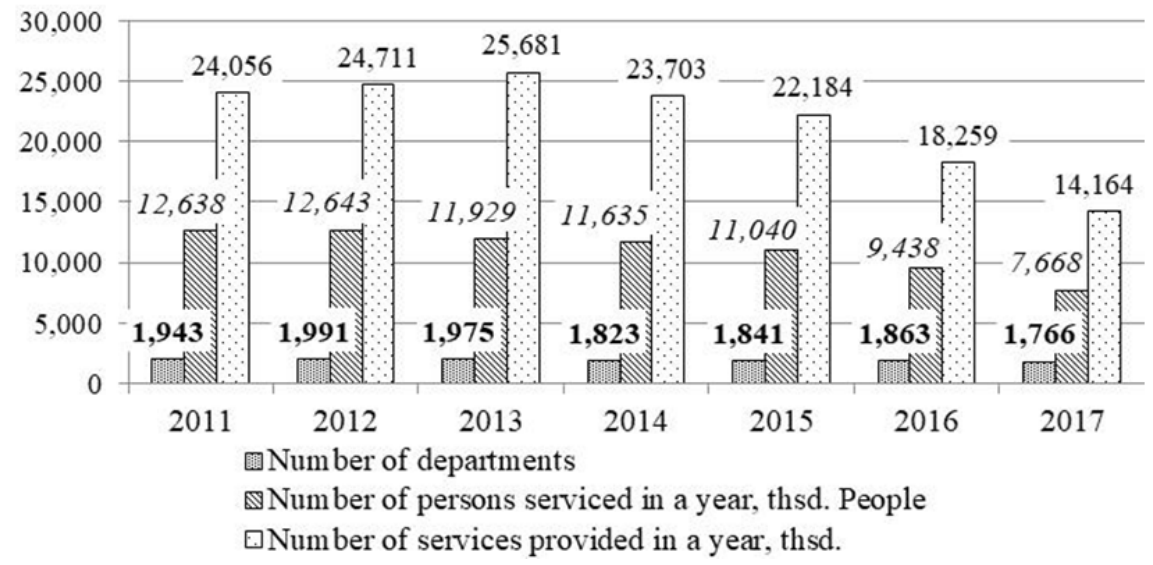

Figure 2: Dynamics of key indicators of urgent social services for senior and disabled citizens in the Russian Federation

Source: Authors based on the sources (Passport of the National Project "Demography", 2018; Passport of the Federal Project "Senior Generation", 2019; Retirement Insurance for Seniors, 2019; Russian Federation Government Decree from 15.04.2014 N 296, 2014; Social Services for Senior and Disabled Citizens, 2019)

The analysis of the key indicators of the urgent social services for senior and disabled citizens in the Russian Federation for 2017 revealed a decline versus 2011 in:

- $\quad$ the number of agencies for urgent social services - by $9.1 \%$ (177 agencies);

- $\quad$ the number of persons serviced - by $39.3 \%$ (4970 thsd. people);

- the number of provided services - by $22.4 \%$ (9892 thsd.).

Dynamics of the number of centers and departments for the in-home social services for senior and disabled citizens in the Russian Federation is shown in Figure 3.

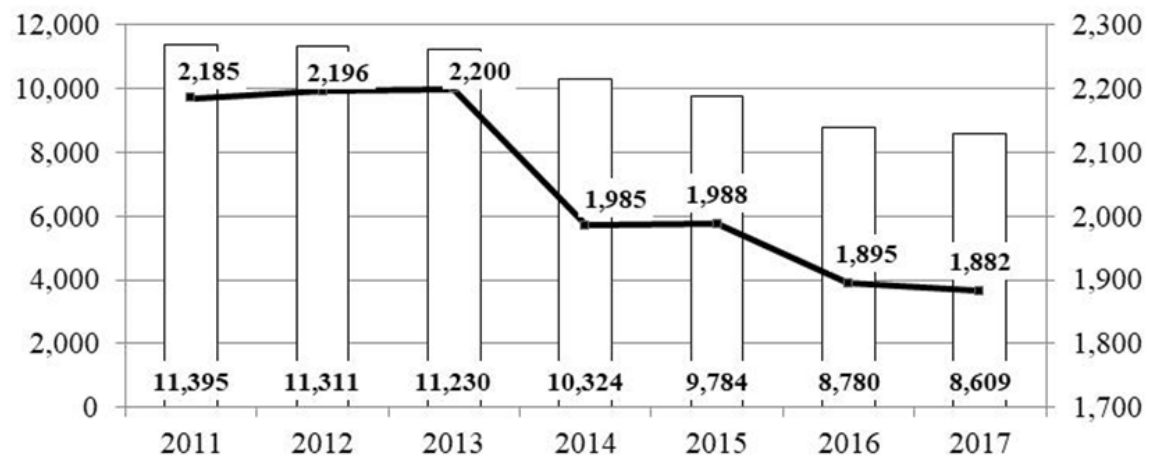

$\square$ Number of in-home social service departments - Number of social service centers

Figure 3: Key indicators of infrastructure for in-home social services to the senior and disabled citizens in the Russian Federation

Source: Authors based on the sources (Passport of the National Project "Demography", 2018; Passport of the Federal Project "Senior Generation", 2019; Retirement Insurance for Seniors, 2019; Russian Federation Government Decree from 15.04.2014 N 296, 2014; Social Services for Senior and Disabled Citizens, 2019) 


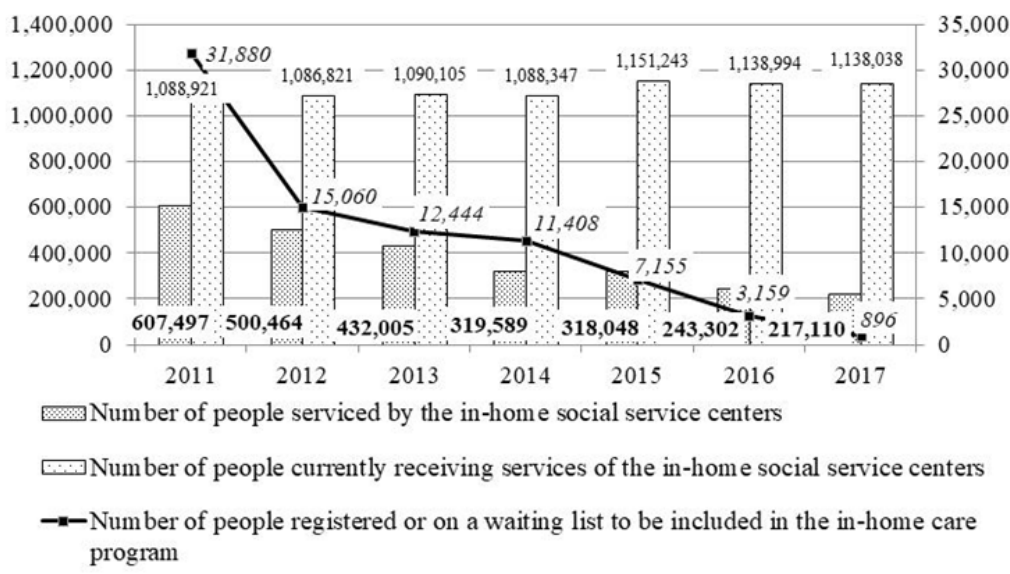

Figure 4: Number of the senior and disabled citizens serviced and registered in in-home social services centers and departments in the Russian Federation, persons

Source: Authors based on the sources (Passport of the National Project "Demography", 2018; Passport of the Federal Project "Senior Generation", 2019; Retirement Insurance for Seniors, 2019; Russian Federation Government Decree from 15.04.2014 N 296, 2014; Social Services for Senior and Disabled Citizens, 2019)

Figure 4 shows that from 2011 to 2017 the number of persons serviced in the in-home social services centers reduced by $64.3 \%$ (from 607,497 down to 217,110 persons). There has been recorded an increase in the number of persons registered (by 1.6\%) and serviced (by $4.5 \%$ ) in the in-home social services departments over the analyzed period of time. There is a decline in the number of citizens on the waiting list to be included in the in-home care program: from 31,880 persons in 2011 down to 896 persons in 2018, or a decline by $97.2 \%$.

Analysis of dynamics of the key indicators of specialized in-home social and medical services for senior and disabled citizens and the persons receiving such services in the Russian Federation from 2011 through to 2017 is presented into Figure 5.

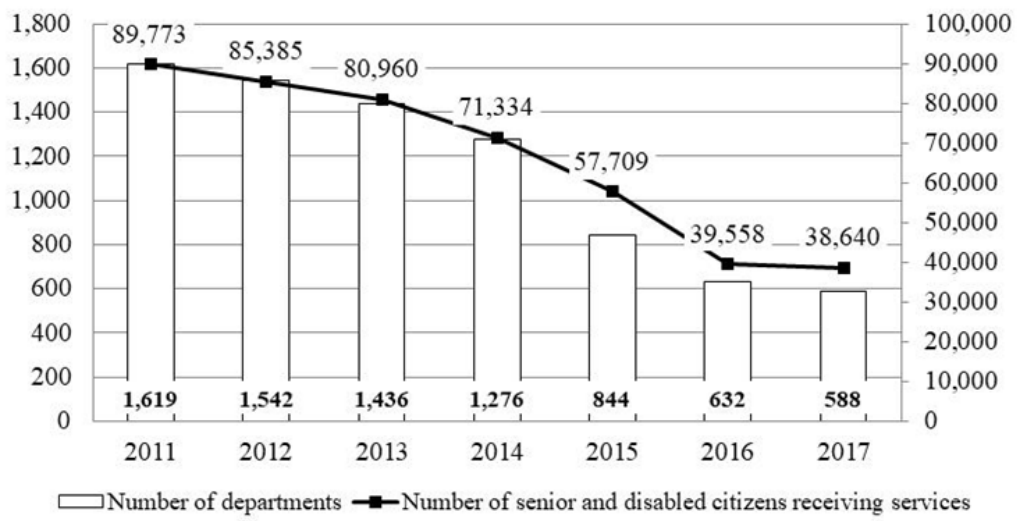

Figure 5: Dynamics of the key indicators of specialized in-home social and medical services for senior and disabled citizens and the persons receiving such services in the Russian Federation

Source: Authors based on the sources (Passport of the National Project "Demography", 2018; Passport of the Federal Project "Senior Generation", 2019; Retirement Insurance for Seniors, 2019; Russian Federation Government Decree from 15.04.2014 N 296, 2014; Social Services for Senior and Disabled Citizens, 2019) 
Number of specialized departments for in-home social and medical services for the senior and disabled citizens in the Russian Federation has reduced by $63.7 \%$ and in 2017 comprised 588 organizations.

The dynamics of the number of residential social care facilities for the senior and disabled citizens is shown in Figure 6.

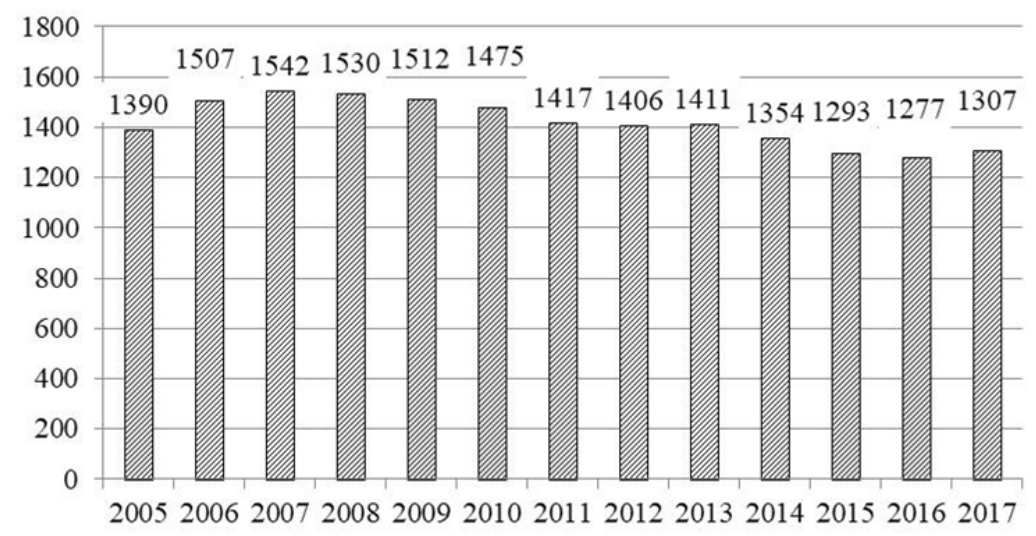

Figure 6: Dynamics of the number of residential social care facilities for senior citizens in the Russian Federation

Source: Authors based on the sources (Passport of the National Project "Demography", 2018; Passport of the Federal Project "Senior Generation", 2019; Retirement Insurance for Seniors, 2019; Russian Federation Government Decree from 15.04.2014 N 296, 2014; Social Services for Senior and Disabled Citizens, 2019)

As evidenced by Figure 6, from 2005 to 2017 the number of residential social care facilities for the senior and disabled citizens reduced by 83 organizations or by $6.0 \%$ (from 1390 down to 1307). Let's examine the dynamics of the number of residential social care facilities for the senior and disabled citizens across the districts of the Russian Federation (Table 1).

Table 1: Number of residential social care facilities for senior and disabled citizens by districts

\begin{tabular}{|l|c|c|c|c|c|c|}
\hline District & 2012 & 2013 & 2014 & 2015 & 2016 & 2017 \\
\hline Central Federal District & 392 & 377 & 329 & 312 & 312 & 316 \\
\hline Volga Federal District & 291 & 317 & 309 & 269 & 253 & 278 \\
\hline Siberian Federal District & 213 & 209 & 203 & 226 & 228 & 219 \\
\hline Northwestern Federal District & 180 & 179 & 173 & 157 & 155 & 152 \\
\hline Southern Federal District & 118 & 117 & 127 & 125 & 126 & 126 \\
\hline Ural Federal District & 91 & 88 & 92 & 88 & 86 & 82 \\
\hline Far Eastern Federal District & 82 & 85 & 83 & 79 & 80 & 94 \\
\hline North Caucasian Federal District, incl.: & 39 & 39 & 38 & 37 & 37 & 40 \\
\hline Stavropol Region & 21 & 21 & 21 & 21 & 21 & 21 \\
\hline
\end{tabular}

Source: Authors based on the sources (Passport of the National Project "Demography", 2018; Passport of the Federal Project "Senior Generation", 2019; Retirement Insurance for Seniors, 2019; Russian Federation Government Decree from 15.04.2014 N 296, 2014; Social Services for Senior and Disabled Citizens, 2019)

Capacity of residential social care facilities for the senior and disabled citizens by federal districts of Russia is provided in Table 2. 
Table 2: Capacity of residential social care facilities for senior and disabled citizens by districts

\begin{tabular}{|l|c|c|c|c|c|c|}
\hline District & 2012 & 2013 & 2014 & 2015 & 2016 & 2017 \\
\hline Central Federal District & 96.2 & 95.9 & 96.7 & 97.2 & 96.9 & 114.1 \\
\hline Northwestern Federal District & 99.9 & 100.3 & 100.2 & 98.2 & 100.1 & 100.8 \\
\hline Southern Federal District & 101.5 & 101.4 & 101.5 & 100.7 & 99.1 & 105.5 \\
\hline North Caucasian Federal District, incl.: & 103.4 & 92.9 & 95.1 & 97.7 & 92.2 & 92.7 \\
\hline Stavropol Region & 101.1 & 101.4 & 101.5 & 98.8 & 102.1 & 101.9 \\
\hline Volga Federal District & 97.7 & 98.3 & 98.0 & 98.8 & 98.4 & 109.5 \\
\hline Ural Federal District & 101.6 & 100.7 & 99.8 & 100.0 & 99.6 & 98.5 \\
\hline Siberian Federal District & 98.9 & 99.3 & 98.8 & 99.4 & 100.4 & 102.0 \\
\hline Far Eastern Federal District & 97.7 & 100.2 & 98.9 & 99.7 & 100.1 & 123.2 \\
\hline
\end{tabular}

Source: Authors based on the sources (Passport of the National Project "Demography", 2018; Passport of the Federal Project "Senior Generation", 2019; Retirement Insurance for Seniors, 2019; Russian Federation Government Decree from 15.04.2014 N 296, 2014; Social Services for Senior and Disabled Citizens, 2019)

In 2017, the Far Eastern Federal Districts the residential social care facilities for senior and disabled citizens were filled up by $123.2 \%$. The capacity of residential social care facilities for the senior and disabled citizens is used by $92.7 \%$ in the North Caucasian Federal District.

Let's analyze the number of social recreation and social rehabilitation centers servicing the senior and disabled citizens in the Russian Federation (Table 3).

Table 3: Dynamics of indicators of social recreation and social rehabilitation infrastructure for senior and disabled citizens in the Russian Federation

\begin{tabular}{|l|c|c|c|c|c|c|c|}
\hline & 2011 & 2012 & 2013 & 2014 & 2015 & 2016 & 2017 \\
\hline Number of social recreation centers & 31 & 38 & 42 & 37 & 35 & 51 & 50 \\
\hline Number of places in the centers & 2412 & 2913 & 3201 & 3100 & 2836 & 4977 & 5142 \\
\hline Number of social rehabilitation centers & 556 & 687 & 825 & 864 & 869 & 840 & 818 \\
\hline Number of places in the centers & 9994 & 10539 & 14005 & 13996 & 13233 & 11843 & 12521 \\
\hline
\end{tabular}

Source: Authors based on the source (Social Services for Senior and Disabled Citizens, 2019)

Analysis of the number of senior and disabled citizens serviced in the social recreation and social rehabilitation centers is provided in Figure 7.

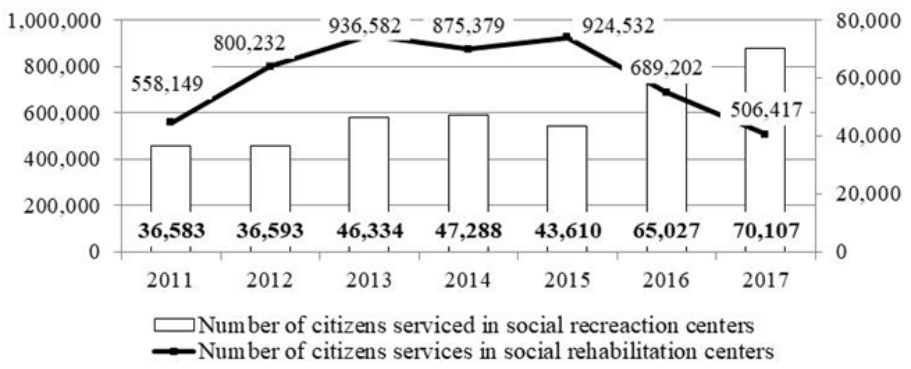

Figure 7: Number of Citizens Serviced in Social Recreation and Social Rehabilitation Centers, persons

Source: Authors based on the sources (Passport of the National Project "Demography", 2018; Passport of the Federal Project "Senior Generation", 2019; Retirement Insurance for Seniors, 2019; Russian Federation Government Decree from 15.04.2014 N 296, 2014; Social Services for Senior and Disabled Citizens, 2019)

The significant flaws of the current social service system include the outdated material and technical base of the social service organizations (Pritvorova \& Bektleeva, 2014, p. 70). 


\section{Discussion}

In December 2017, upon instruction of the President of the Russian Federation, the Government of the Russian Federation developed and approved a package of measures to create a system of long-term care (LTC) for senior and disabled citizens (Ponomareva, 2018, p. 10; System of LongTerm Care for Elderly and Disabled Citizens - Pilot Project, 2019; Long-term Care System, 2019).

This system was tested in 2018 in six regions of the Russian Federation. In 2019 six more regions were added to the pilot project for LTC creation. It is worth noting that by 2022 the project will be rolled out throughout the entire territory of the Russian Federation (System of Long-Term Care for Elderly and Disabled Citizens - Pilot Project, 2019).

Long-term care is a complex system designed to meet the needs of a person who is incapable of self-care (Shestakova, 2017, p. 45; Shestakova, 2015, p. 109; Draskovic et al., 2017).

Organizational support to LTC is presented in Figure 8.

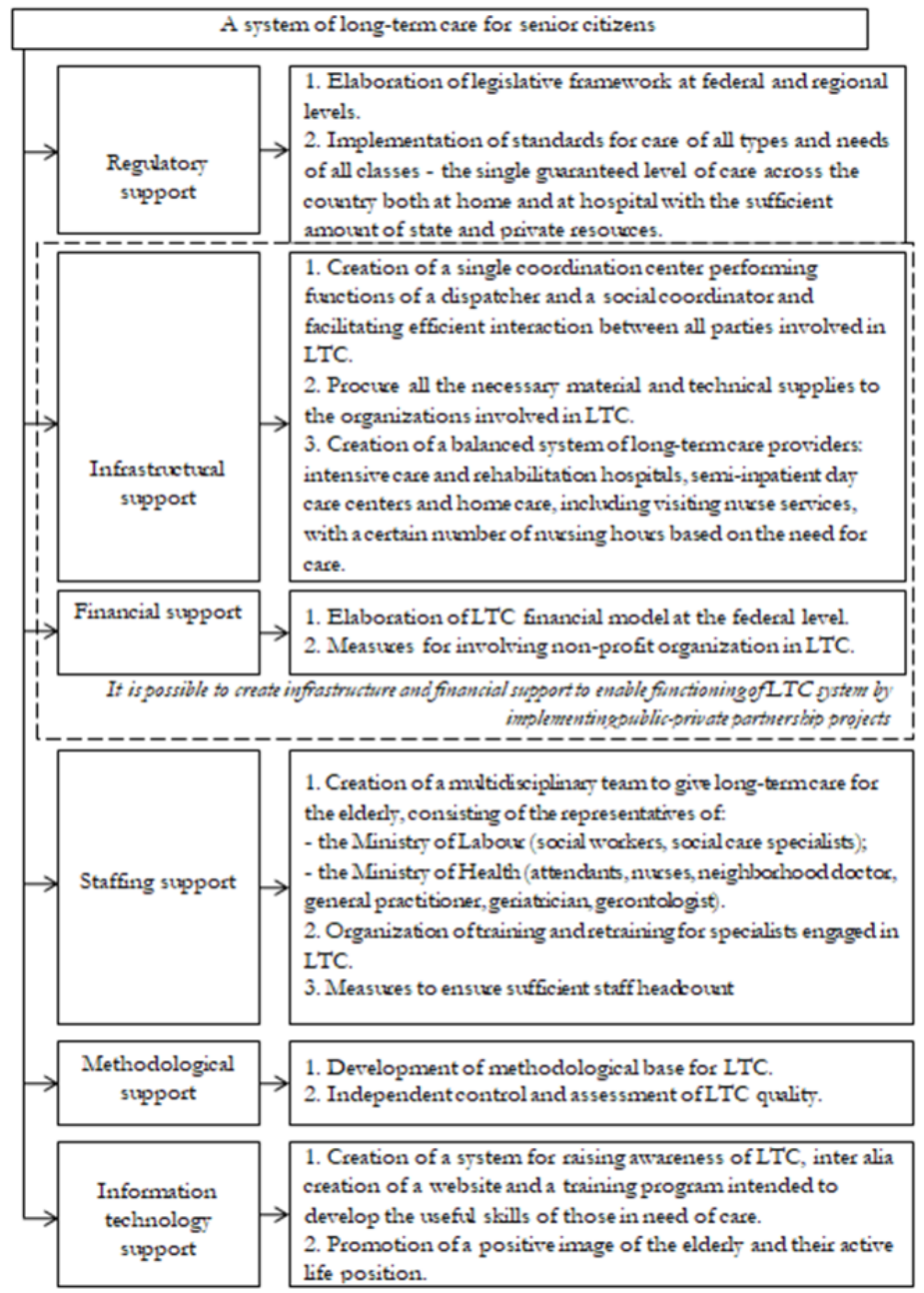

Figure 7: Implementation of long-term care system in the Russian Federation

Source: Authors based on the sources (Chubarova, 2015, p. 45; Sudyin \& Isaakova, 2018, p. 86; Shestakova, 2017, p. 51; Shestakova, 2015, p. 113) 
For the long-term care system to be effectively introduced and functioning in the Russian Federation at present day it is necessary to take the following steps:

1. Develop and introduce a system for identifying the needs in long-term care.

2. Create a register of people in need of long-term care based on internationally accepted assessment (typification) tools, and using certain criteria such as financial security or the social status of an elderly person in need of care.

3. Define the methods of care and places for long-term care (routing).

4. Develop and implement unified standards of rehabilitation and care, standards for control over the care process and results.

5. Create a single coordination center.

6. Update federal and regional regulatory legislation.

7. Establish a functioning system of staffing support that would rely on professional standards, staff schedules of LTC organizations, educational and methodological basis for training and retraining of LTC specialists.

8. Ensure conditions for the development and support of informal (neighborhood/family) care as a key segment of LTC, which includes training, informing, incentivizing and compensation mechanisms and support for people who provide informal care at home.

9. Create a system for raising awareness of LTC, inter alia creation of a website and a training program intended to develop the useful skills of those in need of care.

10. Create a balanced system of inpatient and semi-inpatient institutions providing long-term care and home-based care, with caregivers and visiting nurse services.

\section{Conclusion}

Analysis of demographic ageing trends in the Russian Federation over a span of time from 2011 to 2018 revealed the below problems:

- Steady increase in the number of elderly citizens in the total population of the Russian Federation;

- Decrease in the number of organizations providing social services in residential and semiinpatient forms, and at home for the senior citizens in most federal districts of Russia;

- Decrease in the number of services provided to the senior citizens;

- Insufficient capacity of residential social care facilities for the senior citizens.

When implementing these measures, in our opinion, it is necessary to apply a mechanism of public-private partnership, when the projects are implemented in a way accounting for the interests of society, the state and business (Samofatova, 2017, p. 1214).

\section{References}

Andryushchenko, G.I. (2011). Current trends in the evolution of social insurance systems. Business in Law, 3, 161-164.

Babakaev, S.V., Vinogradova, M.V., Goncharov, P.K., Dolgorukova, I.V., Kaurova, O.V., Kireev, E.Yu, Koludarova, S.V., Maloletko, A.N., Sizikova, V.V., Tanatova, D.K., Timoshina, E.N., Firsov, M.V., Shimanovskaya, Ya.V., \& Yudina, T.N. (2016). Assessment of the quality of services provided by social service organizations. All-Russian Research Project "Assessment of the Quality of Services Provided by Social Service Organizations". Moscow.

Chubarova, T.V. (Ed.) (2015). Social sphere in modern economy: Questions of theory and practice. St. Petersburg: Nestor-History.

Draskovic, M., Milica, D., Mladen, I., \& Chigisheva, O. (2017). Preference of institutional changes in social and economic development. Journal of International Studies, 10(2), 318-328.

Federal Law of the Russian Federation from 28.12.2013 N 442-FZ "On the Fundamentals of Social Services for Citizens in the Russian Federation" (2013). (Revision from 07.03.2018). Retrieved from http://www.consultant.ru/document/cons_doc_LAW_156558/on March 7, 2019.

Kornilova, M.V. (2017). Social service as a way to protect elderly Muscovites from social risks. Social Policy and Sociology, 16(3), 112-119.

Long-term Care System. (2019). Retrieved from https://asi.ru/elderly_care/ on March 7, 2019. 
Marquand, B. (2016). Long-Term Care Insurance Explained. Retrieved from https://www.nerdwallet.com/blog/insurance/long-term-care-insurance/ on March 7, 2019.

Matthews, J.L. (2018). Long-Term Care. How to Plan \& Pay for It. Berkeley, CA: Nolo.

Organization of Long-Term Care for the Elderly and Disabled in Moscow (2019). Retrieved from http://gerontolog.info/ on April 8, 2019.

Passport of the National Project "Demography" (2018). Retrieved from https://rosmintrud.ru/ministry/programms/demography on March 7, 2019.

Passport of the Federal Project "Senior Generation" (2019). Retrieved from https://rosmintrud.ru/ministry/programms/demography/3 on March 7, 2019.

Ponomareva, T.A. (2018). Care for senior generation. Long-term care system for elderly and disabled people in Khanty-Mansiysk Autonomous District-Yugra. In: A.V. Sutula (Eds.), Implementation of the state policy for elderly citizens, ensuring a decent level and quality of life: Materials of $22^{\text {nd }}$ Interregional Scientific Social Readings, October 25-26, 2017. Surgut: Publishing house of the budget institution of Khanty-Mansiysk Autonomous District - Ugra "Methodical center for the development of social services", 10-13.

Retirement Insurance for Seniors (2019). Retrieved from http://www.gks.ru/wps/wcm/connect/rosstat_main/rosstat/ru/statistics/population/generation/\# on March 7, 2019.

Russian Federation Government Decree from 15.04.2014 N 296 (revision from 30.12.2018) "On Approval of the State Program of the Russian Federation "Social Support for Citizens" (2014). Retrieved from http://base.garant.ru/70644062/ on March 7, 2019.

Pritvorova, T.P., \& Bektleeva, D.E. (2014). Management of long-term care system for elderly people in Kazakhstan in the context of effective practices of developed countries. Bulletin of the Omsk University. Series "Economics", 2, 70-78.

Samofatova, K.A. (2017). Capital investments in social infrastructure in the Russian Federation: Public and private investments. Economy and Entrepreneurship, 8-3(85), 1209-1214.

System of Long-Term Care for Elderly and Disabled Citizens - Pilot Project (2019). Retrieved from mintrudsoc.ryazangov.ru on March 7, 2019.

Shestakova, E.E. (2017). Ageing community: in search for an optimal long-term care model. Bulletin of the Institute of Economics under the Russian Academy of Sciences, 4, 45-59.

Shestakova, E.E. (2015). Organization and funding the long-term care for the elderly: Experience of OECD countries. Healthcare Management, 3(45), 109-122.

Social Services for Senior and Disabled Citizens (2019). Retrieved from http://www.gks.ru/wps/wcm/connect/rosstat_main/rosstat/ru/statistics/population/generation/\# on March 7, 2019.

Sudyin, S.A., \& Isaakova, I.A. (2018). New paradigm of aging in a Russian way. Social Policy and Sociology, 17(3), 83-90.

Ulyanchenko, I.I., Gudarenko, R.F., Gudarenko, P.V., Ivannikov, V.F., Bagmet, K.V., Miroshnichenko, R.V., Mukhoryanova, O.A., Andikaeva, K.A., \& Ledeneva, E.O. (2016). Social innovations: Dissemination of modern practices of social service organizations based in Stavropol Region. Stavropol: FSBEI HPE "Russian State Social University" Branch in Stavropol.

Vlasova, T., Scherbak, N., \& Bondarchuk, A. (2018). Long-Term Care for the Elderly: State Support, Pros and Cons. Retrieved from http://xn—__tbcbmcsgqaezl.xn—p1ai/stati/dolgovremennyj-uhod-za-pozhilymi/ on March 7, 2019. 